\title{
Workshop Words Worth Recall
}

\section{THE EDITOR AND THE PUBLICATION OF RESEARCH IN LIBRARIANSHIP}

One does not design research with a view of publication in a particular kind of journal. One can present the results of research in a variety of ways: as a monosyllabic discourse intelligible to a high school football team, for example, or as a complex series of equations covering half a dozen pages with a kind of hieroglyphics that are intelligible to only two living souls: the author and one other-and the latter may well be incarcerated in the Gulag Archipelago. The research process itself, however, is always designed to investigate a problem in such a way as to obtain evidence that will support one solution over a potentially infinite number of conceivable solutions. It is a process of reducing alternatives; of cutting speculation to the quick; of asking questions and finding verifiable answers to them. The questions can be more or less interesting, insightful, important, practical or theoretical; and the process of finding answers can be more or less rigorous, can raise more or fewer questions in its turn, can lead to more or less definite, complete, believable, useful answers. Yet this is all the process involves: asking investigable questions, devising ways of finding objective evidence for answering them, and evaluating the evidence once obtained to see how good it is and how far it goes in providing one with answers. It is a flexible process. There is no formula for doing research. It involves creativity and imagination in thinking up questions and methodologies, and analytic rigor or incisiveness in evaluating evidence. Regarded as a process of asking questions and fining evidence, there is nothing mysterious or forbidding or exclusive about research. The most nothing mysterious or tox methodologies, the most high falutin statistical procedures involving
the entire Greek alphabet in both upper and lower case, are all refinements directed at assuaging the natural skepticism of our common sense when it causes us to ask: how can you say that? How do you really know that? How sure can you be of what you say? Anyone who cannot translate the rationale for, and the results of, complicated research designs and elaborate statistical analyses of data into plain English prose, has not understood what he or she has done....

Having completed research of some kind, how does one decide how to write it up and where to send it for publication once it is written up? Three factors should enter into the decision one makes: 1) an evaluation of what one has done; 2) a determination of the nature of the audience or audiences one wants to reach and 3 ) the requirements of journals that one judges might be interested in the papers one may prepare about one's work. Of course considerations of these factors are not mutually exclusive.

How important and complex was the problem investigated? How close to matters of practice was it? Were the results fairly complete, firm and reliable or were they merely tenatative and suggestive? What do their implications 
seem to be? Into what professional or scholarly fields do they ramify? Was the methodology more interesting than what it was used for or revealed? Answers to these questions help one evaluate the significance or value of what one has done. One can go on to ask: to whom do I wish to communicate my work - as many as possible throughout the whole profession? To those working in my own area of practice or of research in librarianship or to those in a related discipline of which I consider myself also a member? To a limited scholarly community able to assess my work on its merits as research or to fellow workers? To a general, intelligent, well-informed community at large for whom my work may have interest? Answers to these questions lead one to decide on the kind of journal one may wish to publish in: a scholarly professional journal or a popular or rather practical professional one; a scholarly journal in a related field or a solid journal of a general nature. The choice of a journal will determine the kind of article one will try to write and the distance one will try to achieve from the detail of one's research in one's account of it. The latter point is an important one.

Having come to some synthesis of answer to the questions I have raised, what are the kinds of articles that one might try to write? There could be a comprehensive technical account dealing with methodological and interpretive detail supported by a full scholarly apparatus of footnotes, charts, tables, and so on. There could be a brief technical note about one or more aspects of what was done or discovered. These would keep close to the detail of the research and one would try to place such articles in scholarly journals in one's own or related fields. One could prepare a popular account stressing the interesting aspects of the problem one investigated from a professional or practical point of view and the nature of the results are obtained. Or one could prepare a general account in which are examined the implications of one's work for higher education, or policy formulation, or local government or the management of science; ... Such general articles as these are removed to greater or lesser degrees from the details of research no matter whether they are addressed to a professional community or to a more general scholarly community. Frequently, a single piece of research is made the basis of several different kinds of paper in order that it may reach quite different yet appropriate specialist and general audiences....

Let me summarize what I think the main function of the editor is when it comes to the publication of research in librarianship. Simply, it is to work with authors as closely as necessary to achieve papers that meet the highest standards of scholarly communication. Editors are anonymous sorts of people. They should be supportive, critical, sensitive to what is being presented, and they should be aware of and insist on the highest possible standards. They react to what others do. In a most important sense this work is not creative ... But ultimately good research depends on the imagination, the training and the dedication to scholarly ideals of researchers and the authors they become when they carry out their obligation of communicating the results of their work. The editor is there to help.

NOTE: This is an excerpt from the address by $W$. Boyd Rayward at the Library Research for Librarians Workshop on March 8, 1979, at the University of North Carolina-Chapel Hill. Mr. Rayward is editor, Library Quarterly. 


\section{"LIBRARY SERVICE FOR SPECIAL PEOPLE"}

Some 60 persons from North Carolina got up-to-date, detailed and practical information on how to better serve the educational needs of the blind and other handicapped at the all-day workshop at Lenoir Community College on Tuesday, June 19, 1979.

The program centered on the theme "Library Services for Special People" and co-sponsors were Lenoir Community College and the Department of Library Science Alumni Association at East Carolina University.

Ms. Emily Boyce, alumni advisor and workshop moderator, opened the session and Mrs. Mildred Matthis, associate dean of Learning Resources at LCC, welcomed the group to the campus. Dr. Gene D. Lanier, Chairman of the Department of Library Science at ECU, made introductions.

Director Frank Kurt Cylke of the Division of the Blind and the Physically Handicapped at the Library of Congress in Washington, D.C. delivered the keynote speech. He shared in detail the roster of special services available at the Library of Congress and discussed how the program is carried out. A packet of informational materials giving the varied services offered was presented to all registrants.

Mr. Cylke described his responsibilities as those of coordination and money raising. The Division not only selects and purchases books for conversion for the handicapped, but it is extensively involved in designing machinery for use of the materials. The selection of books is influenced by the fact that sixty per cent of the users are over sixty-five years old and only about ten per cent are young children. The annotations in Talking Book Topics include information concerning strong language and explicit descriptions of sex, not for censorship, but to give individuals a choice. Mr. Cylke stated that reader input was a heavy factor in selection.

The participants were interested in the fact that, while the forty-one year old Division began serving adults with Braille, today approximately ninety-five per cent of the blind cannot read braille. The Division must therefore choose not only the materials but the medium of braille, talking-book records and cassettes.

The collection of the Division is loaned free to qualified individuals who cannot hold, handle, or read conventional material.

The Division's 1978 appropriation totaled $\$ 28,720.700$ and was aug. mented by state and local funds for regional and sub-regional libraries across the Nation. The combined federal, state and local funds for such services in 1978 totaled $\$ 41,000,000$. About 571,000 readers (adults and children) were served in fiscal 1977. An estimated 2,000,000 are eligible for such services through-out the country, however.

Penny Hornsby, assistant regional librarian and Bonnie Peele, special project librarian in the North Carolina Library for the Blind and Physically Handicapped, spoke briefly at the forenoon session. After lunch at the Holiday Inn, the delegates attended discussion groups on special services. Participants were Mrs. Betty Phillips Floars of the N. C. School for the Deaf, Wilson, citing services for the deaf; Dr. Carol Veitch, assistant professor at ECU, and Joe Stines, children's librarian at Sheppard Memorial Library in Greenville, who discussed story-telling for the exceptional child; Ann Davis and Susan Lanier of Greenville City Schools emphasized resources for the gifted and talented, and services in academic libraries for the special student were reviewed by Reference Librarian Ralph Scott of the ECU Joyner Library in Greenville.

Alumni Association President Jane Alligood summarized the session at the close. 


\section{Public Library Information and Referral in North Carolina}

Information and Referral Services in North Carolina public libraries have had their ups and downs, but there are several operations still thriving.

The most visible of these operations for many years was the Wake Information Center operating out of the Olivia Raney Library in downtown Raleigh. Library Services and Construction Act (LSCA) funds, plus an infusion from Title XX through a contract with the Wake County Department of Social Services, supported a sizable staff that made over 40,000 I\&R contacts during its best year. The Information Center proper was supplemented for a couple of years by an Adult Learning Information Center funded through a grant to a consortium of local colleges and universities. However, the federal funds began to dry up in 1977, and by February, 1978, Wake Information Center was forced to operate with what little local money was available. As a result, Carol Reilly, the current director of Wake Information Center, now does I\&R parttime and serves as parttime consultant for three branches in the County library system. Her staff consists of a halftime clerk with a background in psychology, human relations, crisis intervention, college teaching and volunteer training. This much smaller although obviously well-qualified staff takes telephone queries from 9 a.m.-11 a.m. daily; after that, the reference staff takes over. The service is less visible than before, having been physically moved from its prime location on the ground floor to the basement so there are fewer walk-ins, with total queries in 1978-79 falling under 5000. There are also no longer any specialized directories being printed, although the fifth edition of HELP for Citizens of Wake County, the prototype community resources directory in the state, is now available for $\$ 1.00$ a copy. This is the first edition for which it has been necessary to charge.

Wake Information Center's experience with federal money flowing and then rather abruptly drying up might make others think twice before taking the initial plunge. However, Ms. Reilly does not discourage others from applying for grants. Wake did get all the funding it requested, and the grants were for the maximum periods of time; so, during that time, Wake boasted a large, effective organization that benefitted many thousands of people. What Ms. Reilly would suggest is early planning for the days when federal funding is no longer available.

The Pitt County Information Center was another early I\&R operation in the state. Begun in a branch in 1974 with LSCA funds, the center has now been assumed with local funding and operates out of the Main Library as Sheppard Information Center. Feeling on the part of local funding bodies was that it was somehow a more legitimate library program if it operated out of the main library.

The Sheppard Information Center is a one-woman operation that is primarily a telephone service. The one woman, Carolyn Hibbard, also does outreach by speaking to groups and presenting audiovisual programs on such topics as consumer survival and health. She often also takes along another authority to speak on whatever topic is to be discussed. 
The Sheppard Information Center is strong on interaction with other groups in the community, and helped the League of Women Voters compile a Community Service Guide for Pitt County.

Information and Referral came to Central North Carolina Regional Library in 1978, again through a Library Services and Construction Act grant. This is a two-county library system, and the I\&R set-up is really two separate operations, run in Chatham County by Lilly Beth Goldston and in Alamance by Gayle Fischel. Susan Kern is overall coordinator of the program.

In Chatham County, a toll-free line is available for all major exchanges. In Alamance, there is a connecting line with the Health Information Office; referrals go both ways. Chatham has published a Directory of Agencies and Services Serving Chatham County for use by agencies in the county. Alamance has done three directories in cooperation with other organizations: Consumer Survival Guide, with VISTA; Services for Parents and Children, with Mental Health and child abuse groups; and The Answer Book, an update of services for the elderly.

Coordinator Kern says that the best advertising for CNCRL's I\&R has been through the directories they publish and bulk/occupant mailings.

Two new I\&R projects were funded by LSCA grants in July of 1979, one in Davidson County and one in Pender County.

Davidson Information Assistance Line (DIAL) is available toll-free throughout the county. Library Director Nancy Fullbright relates that three staff were hired to run the project, and that as a result of the project, library hours have been increased to enable library staff to take more calls. A unique feature of DIAL is that the Sheriff's Department answers the line when the library is closed. Being on a County switchboard and having strong backing from county officials can be a big asset.

Pender County Library's Neighborhood Information Van project is the state's only mobile I\&R service, and the only one designed to serve rural residents. The van travels to three community centers located in sparsely populated areas of the county and provides direct service in remote areas to those without transportation. Verne Oleksowicz is the Neighborhood Information Van project director.

The Durham County Library has just published the 1979 Directory of Community Resources in cooperation with HASSLE House (which provides free crisis and suicide counseling and gives referrals to other community resources according to the directory). The directory is modelled on the Wake County HELP booklet and was coordinated by Nancy Bivod. Work on the directory was funded through LSCA Outreach Enrichment money. Durham County has also done educational brokering through Project LIFT, financed with an HEA grant co-sponsored by the library, North Carolina Central University, Duke, Durham Technical Institute and Durham County Community Education. However, this grant is running out, so continuation of the service is not assured at this time.

Most of the I\&R services mentioned above use Employment Security Commission and CARE-LINE microfiche as important resources for the information that they provide. They are also generally concerned that I\&R services be integrated to some degree into general library operations, since there are always times when I\&R staff are not available to take queries. And, what has been overwhelmingly influential in the development of Information and Referral Services in North Carolina is the availability of Library Services and Construction Act funds to initiate the projects. After that funding runs out, the local funding situation will determine continuation of the service. Patsy Hansel 